\title{
PENGARUH IFR DAN TINGKAT PENGUNGKAPAN INFORMASI TERHADAP NILAI PERUSAHAAN DENGAN RELEVANSI NILAI SEBAGAI VARIABEL INTERVENING
}

\author{
Anisa \\ Universitas Pamulang \\ dosen02385@unpam.ac.id
}

\begin{abstract}
This research is conducted to investigate Internet Financial Reporting (IFR) and the level of information disclosure on firm value with the value relevance of accounting information as an intervening variable. This research used secondary data for the period 2008-2019 on banking companies listed on the Indonesia Stock Exchange. The sampling technique used saturated sampling. Tools for processing data using SPSS 22. Data analysis using path analysis. The results showed that IFR and the level of information disclosure had a positive effect on value relevance when tested simultaneously. The higher the application of IFR and the level of information disclosure the higher the value relevance. Meanwhile, IFR and the level of information disclosure have a negative effect on firm value. The results show that the application of IFR is good and the level of disclosure of the information is fair disclosure, but the market reaction is down, as evidenced by the value of the stock market value is smaller than the book value (undervalue). Value relevance has no effect on firm value. The results showed that the value relevance is high, but the market value is low. So that it has no value for investors in the company to get capital gains. This means that accounting information has lost its function to influence investors in making decisions. However, value relevance itself is a variable that intervenes between IFR and the level of information disclosure simultaneously on firm value..
\end{abstract}

Keywords: IFR; value of the firm; value relevance; disclosure.

\begin{abstract}
Abstrak
Penelitian ini bertujuan untuk menguji pengaruh Internet Financial Reporting (IFR) dan tingkat pengungkapan informasi terhadap nilai perusahaan dengan relevansi nilai informasi akuntansi sebagai variabel intervening. Penelitian ini menggunakan data sekunder periode tahun 2008-2019 pada perusahaan perbankan yang terdaftar di Bursa Efek Indonesia. Teknik pengambilan sampel menggunakan sampling jenuh. Alat untuk mengolah data menggunakan SPSS 22. Analisis data menggunakan analisis jalur atau path analysis. Hasil penelitian menunjukkan IFR dan tingkat pengungkapan informasi mempunyai pengaruh positif terhadap relevansi nilai bila diuji secara simultan. Semakin tinggi penerapan IFR dan tingkat pengungkapan informasi semakin tinggi pula relevansi nilainya. Sedangkan IFR dan tingkat pengungkapan informasi memiliki pengaruh
\end{abstract}

* Corresponding author's e-mail: dosen02385@unpam.ac.id

http://openjournal.unpam.ac.id/index.php/JABI 
negatif terhadap nilai perusahaan. Hasil penelitian menunjukan bahwa penerapan IFR nya baik dan tingkat pengungkapan informasinya pun fair disclosure, namun reaksi pasar nya turun, ini terbukti dari nilai nilai pasar saham lebih kecil dari nilai bukunya (under value). Relevansi nilai tidak memiliki pengaruh terhadap nilai perusahaan. Hasil penelitian menunjukan bahwa relevansi nilai tinggi, namun nilai pasarnya rendah. Sehingga tidak mempunyai value bagi investor di perusahaan untuk mendapatkan capital gain. Hal ini berarti informasi akuntansi telah kehilangan fungsinya mempengaruhi investor dalam pengambilan keputusan. Namun relevansi nilai sendiri merupakan variabel intervening antara IFR dan tingkat pengungkapan Informasi secara simultan terhadap nilai perusahaan.

Kata kunci: IFR; nilai perusahaan; relevansi nilai; disclosure.

\section{PENDAHULUAN}

Perkembangan internet yang semakin pesat secara signifikan telah mempengaruhi perusahaan dalam melaksanakan aktivitas pelaporan bisnis dan praktek komunikasi pencatatan akuntansinya (Rosmaini, Ariff, Kamil, dan Hancock, 2009). Penerapan IFR menyebabkan pelaporan keuangan menjadi lebih cepat dan mudah, sehingga dapat diakses oleh siapa pun, kapan pun dan di mana pun. Saat ini penyebarluasan informasi keuangan melalui internet juga menjadi pilihan yang tepat bagi perusahaan-perusahaan go public karena berbiaya rendah (lowcost) dan dapat memberikan image yang baik bagi perusahaan.

Jika diamati saat ini, perusahaan perbankan sudah jauh lebih baik dalam memanfaatkan website perusahaan dalam berkomunikasi dengan stakeholders. Industri perbankan sendiri merupakan industri dengan regulasi yang ketat. Otoritas Jasa Keuangan $(\mathrm{OJK})$ yang mempunyai fungsi mengatur, mengawasi dan melindungi sektor jasa keuangan dalam hal ini industri perbankan, mengeluarkan sebuah peraturan nomor 37/POJK.03/2019 tentang Transparansi dan Publikasi Laporan Bank. Di dalamnya juga mengatur mengenai sanksi administratif bagi perusahaan yang tidak mengungkapkan laporan keuangannya pada website perusahaan. Hal ini mendorong para pelaku usaha sektor jasa keuangan untuk mempublikasikan laporan keuangannya secara luas dan transparan kepada seluruh stakeholders

Penelitian mengenai IFR yang dilakukan oleh Khan \& Ismail (2011) dalam mengukur tingkat IFR perusahaan yang terdaftar di Bursa Malaysia. Hasil penelitian tersebut menunjukkan bahwa tingkat IFR emiten Bursa Malaysia berkisar dari 48,27\% hingga 78,16\%. Selain itu, Elhelaly \& Mohamed (2014) turut melakukan penelitian mengenai penerapan IFR pada perusahaan-perusahaan di Mesir. Hasil penelitian menyatakan dari 100 perusahaan yang terdaftar diindeks EGX100 di Bursa Efek Mesir yang dianalisis, hanya 36 perusahaan yang menggunakan website dan hanya 29 perusahaan memberikan informasi keuangan di situs web mereka. Penelitian ini mengungkapkan terbatasnya penggunaan internet untuk tujuan pelaporan keuangan di Mesir. Tampak bahwa meskipun penggunaan internet sebagai media untuk penyebaran informasi perusahaan di berbagai wilayah dan Negara di dunia telah meningkat, masih

* Corresponding author's e-mail: dosen02385@unpam.ac.id

http://openjournal.unpam.ac.id/index.php/JABI 
banyak perusahaan yang tidak memiliki website perusahaan atau tidak menggunakan situs web mereka untuk menyebarkan informasi keuangan tersebut.

Di Indonesia sendiri telah banyak penelitian mengenai penerapan IFR tetapi masih sedikit yang meneliti bagaimana IFR mempengaruhi nilai perusahaan, serta bagaimana IFR mempengaruhi relevansi nilai informasi akuntansi itu sendiri. Hampir keseluruhan penelitian mencoba menelaah faktor penerapan, level pengungkapan IFR dengan beberapa variabel. Ukuran Perusahaan (firm size) merupakan variabel yang paling sering muncul dalam praktek Internet Corporate Disclosure khususnya Internet Financial Reporting (IFR).

Perbedaan penelitian ini dengan penelitian sebelumnya yaitu penggunaan data terbaru dan jenis perusahaan yang berbeda yaitu perusahaan perbankan yang terdaftar di BEI tahun 2008-2019 dengan harapan dapat memperoleh hasil yang lebih akurat. IFR telah membuka sebuah domain penelitian baru pada bidang akuntansi dan keuangan. Nilai Perusahaan dipilih karena dianggap mencerminkan rekasi investor terhadap suatu informasi keuangan. Semakin baik nilai perusahaan maka dapat dikatakan saham tersebut semakin rentan terhadap perubahan akibat adanya informasi yang beredar.

Permasalahan yang ada dalam penelitian ini adalah mengenai hubungan internet financial reporting dan tingkat pengungkapan informasi terhadap nilai perusahaan Tujuan yang ingin dicapai dari penelitian ini adalah untuk menganalisis hubungan internet financial reporting dan tingkat pengungkapan informasi terhadap nilai perusahaan dan menggunakan relevansi nilai sebagai variabel intervening

Diharapkan penelitian ini dapat memperkaya bahan kepustakaan dan mampu memberikan kontribusi pada pengembangan teori, terutama yang berkaitan dengan akuntansi keuangan dan akuntansi sektor bisnis, khususnya untuk memahami peranan dan pengaruh Internet Financial Reporting (IFR) dan tingkat pengungkapan informasi terhadap nilai perusahaan dilihat dari relevansi nilai informasi akuntansi. Dan dapat memberikan kontribusi praktis bagi para investor sebagai pengguna laporan keuangan untuk mendapatkan informasi keuangan dengan lebih cepat dan praktis dengan pengungkapan informasi yang diberikan oleh perusahaan di dalam website-nya. Sehingga investor dapat mengestimasi nilai yang diharapkan (expected value) dari tingkat return dan tingkat risiko dari saham guna memicu investor melakukan tindakan investasi terhadap saham perusahaan. Bagi Perusahaan Go Publik (Emiten) atau pihak yang terkait diharapkan dapat memberikan kontribusi praktis bagi perusahaan (emiten) terkait untuk memaksimalkan peranan Internet Financial Reporting (IFR) dan tingkat pengungkapan informasi terhadap nilai perusahaan dilihat dari relevansi nilai informasi akuntansi itu sendiri.

\section{KERANGKA TEORITIS DAN PENGEMBANGAN HIPOTESIS}

Para investor memiliki kebutuhan untuk dapat memprediksi serta mengetahui nilai dari sebuah perusahaan untuk menentukan apakah perusahaan tersebut memiliki kemampuan untuk memberikan capital gain kepada investor yang berinvestasi pada perusahaan tersebut. Kemampuan informasi akuntansi dalam menjelaskan nilai dari

* Corresponding author's e-mail: dosen02385@unpam.ac.id

http://openjournal.unpam.ac.id/index.php/JABI 
sebuah perusahaan berdasarkan nilai pasarnya dikenal sebagai relevansi nilai informasi akuntansi (Beaver, 1968) dalam Pinasti (2004). Relevansi nilai memiliki kaitan yang erat dengan kualitas informasi akuntansi. Barth, et al. (2008) menjelaskan bahwa perusahaan dengan kualitas informasi yang tinggi memiliki relevansi nilai laba bersih dan nilai buku yang tinggi. Francis dan Schipper (1999) mendefinisikan relevansi nilai informasi akuntansi sebagai kemampuan angka-angka akuntansi untuk merangkum informasi yang mendasari harga pasar saham perusahaan. Oleh karena itu, kualitas informasi akuntansi yang tinggi dapat mengindikasikan hubungan yang kuat antara harga/return saham dengan laba dan nilai buku karena kedua informasi akuntansi tersebut mencerminkan kondisi ekonomi perusahaan (Barth, et al., 2008).

Meningkatnya persaingan informasi di pasar modal menyebabkan pentingnya mengetahui relative importance laporan keuangan. Di sinilah letak kegunaan value relevance: menggambarkan kegunaan informasi laporan keuangan bagi investor relatif terhadap seluruh informasi yang digunakan oleh investor pada pasar modal (Lev dan Zarowin, 1999).

Pinasti (2004) melakukan penelitian mengenai relevansi nilai di Indonesia dengan hipotesis yang diberi nama hipotesis informasi alternatif (alternative information hypothesis) diajukan dalam penelitian ini. Beralihnya perhatian investor kepada sumbersumber informasi alternatif tersebut mengakibatkan menurunnya relevansi nilai informasi akuntansi dari waktu ke waktu. Sebagaimana dinyatakan oleh Rimerman (1990), beberapa kebutuhan informasi pemakai laporan keuangan yang tidak dapat dipenuhi oleh informasi akuntansi, menyebabkan investor berpaling ke informasiinformasi non-akuntansi.

Mengukur relevansi nilai informasi keuangan dengan melihat hubungan informasi keuangan dengan nilai sahamnya dibutuhkan model penilaian. Terdapat dua model penilaian yang umum digunakan untuk menginvestasikan hubungan tersebut yaitu return model dan price model.

Teori sinyal (signaling theory) merupakan salah satu teori yang mendasari penelitian mengenai nilai perusahaan. Menurut Brigham dan Houston (2013) menyatakan bahwa teori sinyal adalah suatu tindakan yang diambil manajemen perusahaan yang memberikan petunjuk bagi investor tentang bagaimana manajemen menilai prospek perusahaan tersebut. Teori ini mengungkapkan bahwa investor dapat membedakan antara perusahaan yang memiliki nilai tingggi dengan perusahaan yang memiliki nilai rendah. Perusahaan yang profitable memberikan sinyal tentang perusahaan yang relative tidak mudah mengalami kebangkrutan dan bentuk lain dari financial distress, dibanding dengan perusahaan yang kurang profitable. Perusahaan dengan prospek yang sangat cerah lebih memilih untuk tidak melakukan pendanaan melalui penawaran saham baru, sementara perusahaan dengan prospek yang buruk memang menyukai pendanaan dengan ekuitas luar (Brigham dan Houston, 2013).

Menurut Soemarso (2003) pengungkapan laporan keuangan dalam makna yang lebih luas berarti penyampaian informasi. Laporan tahunan (annual report) adalah perangkat utama untuk menyampaikan informasi oleh manajemen kepada pihak-pihak diluar perusahaan. Laporan tahunan memberikan informasi mengenai kondisi keuangan perusahaan dan informasi lainnya kepada pemegang saham, kreditor dan para stakeholders. 
Kualitas pengungkapan ditunjukkan dengan tingkat keluasan pengungkapan sebagai salah satu indikator. Semakin luas tingkat pengungkapan maka semakin valid informasi yang diberikan. Tingginya kualitas informasi akuntansi sangat berkaitan dengan tingkat kelengkapan pengungkapan. Chariri (2003) mengidentifikasi konsep mengenai pengungkapan sehubungan dengan kualitas laporan keuangan menjadi tiga, yaitu:

a. Adequate disclosure (cukup)

Tingkat pengungkapan yang memadai adalah pengungkapan yang harus dipenuhi agar laporan keuangan secara keseluruhan tidak menyesatkan bagi pemakai dalam mengambil keputusan.

b. Fair disclosure (wajar)

Tingkat pengungkapan yang wajar adalah tingkat yang harus dicapai agar semua pihak mendapat perlakuan atau pelayanan informasi yang sama.

c. Full disclosure (lengkap)

Tingkat pengungkapan yang penuh menuntut penyajian secara penuh terhadap semua informasi yang berkaitan dengan pengambilan keputusan.

Menurut Soemarso (2003) terdapat dua jenis pengungkapan yang digunakan oleh perusahaan untuk menyampaikan informasi kepada stakeholders, yaitu pengungkapan wajib (mandatory disclosure) dan pengungkapan sukarela (voluntary disclosure).

a. Pengungkapan Wajib (Mandatory Disclosure)

Pengungkapan wajib adalah pengungkapan yang dilakukan oleh perusahaan mengenai informasi-informasi penting yang berkenaan dengan aktivitas dan kondisi perusahaan secara riil dan bersifat wajib serta diatur dalam peraturan hukum (Suwardjono, 2005). Peraturan yang mengatur hal tersebut dikeluarkan oleh pemerintah melalui Keputusan Ketua Bapepam No. Kep-38/PM/1996 tanggal 17 Januari 1996, yang menyatakan bahwa perusahaan yang telah melakukan penawaran umum dan perusahaan publik berkewajiban untuk menyampaikan laporan tahunan. Seiring dengan perkembangan dalam dunia bisnis, peraturan tersebut disempurnakan dalam Keputusan Ketua BapepemLK No. KEP-431/BL/2012.

b. Pengungkapan Sukarela (Voluntary Disclosure)

Pengungkapan sukarela adalah pengungkapan yang dibuat oleh perusahaan diluar dari apa yang diwajibkan oleh standar akuntansi atau peraturan badan pengawas (Suwardjono, 2005). Oleh karena itu tidak semua perusahaan melakukan praktik pengungkapan yang sama, akan tetapi sesuai dengan kebutuhan perusahaan tersebut. Meek et. al., (1995) dalam Murtanto dan Elvina (2005) menegaskan bahwa pengungkapan sukarela merupakan pilihan yang bebas bagi manajemen perusahaan dalam memberikan informasi akuntansi dan informasi lainnya yang dipandang relevan guna pengambilan keputusan oleh para pemakai laporan tahunannya.

Seiring meningkatnya kebutuhan informasi keuangan dari pengguna laporan yang lokasinya tidak terbatas pada satu wilayah negara, menyebabkan laporan keuangan yang disampaikan dengan media kertas kurang mampu menjawab kebutuhan informasi dari pengguna laporan keuangan yang semakin hari semakin meningkat. Perlu sebuah media baru yang mampu menyampaikan informasi 
keuangan secara cepat dan mampu menjangkau semua pengguna laporan keuangan di belahan bumi manapun. Salah satu media yang mampu menyampaikan informasi keuangan secara cepat dan mampu menjangkau semua pengguna laporan keuangan di belahan bumi manapun adalah internet atau website (Asbaugh et al., 1999). Usaha menyampaikan informasi keuangan kepada penggguna laporan keuangan dengan menggunakan media internet atau website disebut Internet Financial Reporting/IFR (Lai et al., 2009).

Laporan keuangan yang baik adalah laporan keuangan yang memiliki informasi yang berguna untuk pengambilan keputusan, salah satunya keputusan untuk menentukan harga saham atau sekuritas (Jones, 2009). Menurut teori efficient market hypothesis, suatu pasar dapat dikatakan efisien apabila harga sekuritas merupakan cerminan informasi yang ada di pasar (Fama, 1990). Teori ini mengasumsikan bahwa investor bersifat rasional, tidak ada biaya untuk mendapatkan informasi dalam pasar, informasi bersifat netral, dan investor akan merespon dengan cepat informasi baru yang tersedia di pasar (Jones, 2009). Dengan adanya asumsi tersebut, informasi yang ada di pasar tersedia bebas untuk seluruh pelaku pasar dan tidak ada satupun pihak dalam pasar yang mendapat abnormal return (Ross et al, 2002).

Nilai perusahaan merupakan pemahaman investor terhadap tingkat keberhasilan perusahaan yang banyak dikaitkan dengan harga saham. Harga saham yang tinggi menjadikan nilai perusahaan pun tinggi. Tujuan utama perusahaan menurut theory of the firm adalah untuk memaksimalkan kekayaan atau nilai perusahaan (value of the firm) (Salvatore, 2005). Meningkatnya nilai perusahaan merupakan sebuah pencapaian yang sesuai dengan keinginan para pemiliknya, karena dengan meningkatnya nilai perusahaan, maka kesejahteraan para pemilik tentu akan meningkat. Nilai Perusahaan sangat penting karena dengan nilai perusahaan yang tinggi akan diikuti oleh tingginya kesejahteraan pemegang saham (Brigham dan Gapensi, 1996). Nilai perusahaan yang tinggi menjadikan pasar yakin dan percaya tidak hanya pada kinerja perusahaan saat ini namun juga pada prospek perusahaan di masa yang akan datang.

Hipotesis pada penelitian ini adalah :

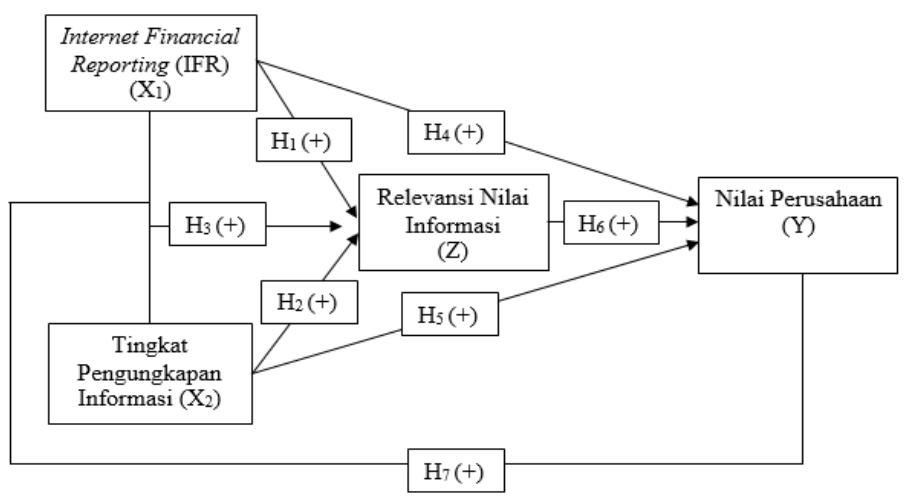

Gambar 2.1. Kerangka pemikiran

* Corresponding author's e-mail: dosen02385@unpam.ac.id

http://openjournal.unpam.ac.id/index.php/JABI 
$\mathrm{H}_{1}$ : Internet Financial Reporting berpengaruh terhadap Relevansi Nilai Informasi Akuntansi.

$\mathrm{H}_{2}$ : Tingkat Pengungkapan Informasi berpengaruh terhadap Relevansi Nilai Informasi Akuntansi.

$\mathrm{H}_{3}$ : Internet Financial Reporting dan tingkat Pengungkapan Informasi Secara Simultan Berpengaruh terhadap Relevansi Nilai Informasi Akuntansi.

$\mathrm{H}_{4}$ : Internet Financial Reporting berpengaruh terhadap Nilai Perusahaan.

$\mathrm{H}_{5}$ : Tingkat Pengungkapan Informasi berpengaruh terhadap Nilai Perusahaan.

$\mathrm{H}_{6}$ : Relevansi Nilai Informasi Akuntansi berpengaruh terhadap Nilai Perusahaan.

$\mathrm{H}_{7}$ : Internet Financial Reporting dan Tingkat Pengungkapan Informasi Secara Simultan berpengaruh terhadap Nilai Perusahaan.

\section{METODE RISET}

Desain yang digunakan dalam penelitian ini adalah statistik deskriptif dan teknik analisis data menggunakan analisis jalur atau path analysis dengan menggunakan SPSS (Statistical Product and Service Solutions) 22.0 for Windows. Dalam penelitian ini, penulis melakukan penelitian dengan metode dokumentasi, studi pustaka dan observasi website perusahaan. Selain itu penelitian ini menggunakan pendekatan kuantitatif, di mana pendekatan ini lebih berdasarkan kepada data yang dapat dihitung untuk mendapatkan menaksiran yang lebih kuat. Variabel-variabel yang akan diuji yaitu IFR, tingkat pengungkapan informasi (disclosure) terhadap nilai perusahaan dengan relevansi nilai informasi akuntansi sebagai variabel intervening.

Dalam penelitian ini populasi yang dipilih adalah seluruh perusahaan Perbankan yang terdaftar di Bursa Efek Indonesia (BEI), terdapat 300 perusahaan selama periode 2008-2019. Teknik pengambilan sampel yang digunakan dalam penelitian ini adalah sampling jenuh.

Internet Financial Reporting (IFR) adalah cara penyampaian informasi keuangan kepada para penggguna laporan keuangan dengan menggunakan perangkat internet atau website (Lai et al., 2009). Jika mempublikasikan laporan tahunan di dalam website perusahaan, diberi skor 1 (satu), bila tidak mempublikasikan, diberi skor 0 (nol).

Tingkat Pengungkapan Informasi (disclosure) pada Chariri (2003) mengidentifikasi konsep mengenai pengungkapan sehubungan dengan kualitas laporan keuangan menjadi tiga, yaitu adequate disclosure (cukup), fair disclosure (wajar), dan full disclosure (lengkap). Kriteria item pengungkapan diadaptasi dari Keputusan Ketua Bapepam-LK (kini OJK) No. KEP431/BL/2012 tentang Penyampaian Laporan Tahunan Emiten atau Perusahaan Publik Peraturan No.X.K.6. Pengurkurannya dengan menggunakan skala rasio dengan rumus sebagai berikut:

Disclosure index $=\frac{n}{k} x 100 \%$

* Corresponding author's e-mail: dosen02385@unpam.ac.id

http://openjournal.unpam.ac.id/index.php/JABI 
Salah satu cara untuk mengukur nilai perusahaan adalah dengan Tobin's $Q$. Klapper dan Love dalam Darmawati dan Khomsiyah (2004) telah menyesuaikan rumus Tobin's $Q$ dengan kondisi transaksi keuangan perusahaan di Indonesia. Rumus tersebut sebagai berikut:

$$
\text { Tobin's } Q=(M E+D E B T) / T A
$$

Di mana:

$$
\begin{array}{ll}
\text { ME } & =\text { Jumlah saham biasa yang beredar dikali harga penutupan } \\
& \text { saham. } \\
\text { DEBT } & =(\text { Total Utang }+ \text { Persediaan }- \text { Aktiva Lancar }) \\
\text { TA } & =\text { Nilai buku total aktiva perusahaan }
\end{array}
$$

Beaver (1968) dalam Pinasti (2004) skala pengukuran yang digunakan

\begin{tabular}{|c|c|c|}
\hline Indikator & Pengukuran & Skala \\
\hline $\begin{array}{l}\text { Internet Financial Reporting } \\
\text { (IFR) (Independen/ X1) }\end{array}$ & $\begin{array}{c}\text { IFR }=1 \\
\text { Non IFR }=0\end{array}$ & Dummy \\
\hline $\begin{array}{l}\text { Tingkat Pengungkapan Informasi } \\
\text { (disclosure) (Independen/ X2) }\end{array}$ & $\begin{array}{l}\text { Disclosure index }=\frac{\boldsymbol{n}}{\boldsymbol{k}} \boldsymbol{x} \mathbf{1 0 0} \% \\
\text { Kriteria Pengungkapan: } \\
\text { - Cukup }(\text { adequate })=0.01-0.40 \\
\text { - Wajar }(\text { fair })=0.41-0.80 \\
\text { - Penuh }(\text { full })>0.80\end{array}$ & Rasio \\
\hline $\begin{array}{l}\text { Nilai Perusahaan (Tobin's Q) } \\
\text { (Dependen/ Y) }\end{array}$ & $\begin{array}{l}\text { Tobin's } \boldsymbol{Q}=(\boldsymbol{M E}+\boldsymbol{D E B T}) / \boldsymbol{T A} \\
\text { Kriteria nilai Tobin's } q \text { : } \\
\text { Over Value }=>1 \\
\text { Fair Value }=1 \\
\text { Under Value }=<1\end{array}$ & Rasio \\
\hline $\begin{array}{l}\text { Relevansi Nilai } \\
\text { (Intervening/ Z) }\end{array}$ & $\begin{array}{l}\quad \mathbf{P i t}=\boldsymbol{\alpha} \mathbf{0}+\boldsymbol{\beta}_{\mathbf{1}} \text { LPSit }+\boldsymbol{\beta}_{\mathbf{2}} \mathbf{N B S i t}+\boldsymbol{E i t} \\
\text { Kriteria Relevansi Nilai: } \\
\text { - Rendah }=0.01-0.40 \\
\text { - Cukup }=0.41-0.80 \\
\text { - Tinggi }>0.80\end{array}$ & Rasio \\
\hline
\end{tabular}
untuk mengukur relevansi nilai adalah dengan menggunakan skala rasio dengan rumus sebagai berikut:

\section{Pit $=\alpha 0+\beta_{1}$ LPSit $+\beta_{2}$ NBSit + Eit}

Tabel 3.1 Pengukuran Variabel

Pengujian terhadap hipotesis dilakukan dengan cara analisis jalur (path analysis) untuk menguji hubungan sebab akibat antar variabel. Analisis jalur menggunakan uji sobel (Sobel Test). Uji sobel dilakukan untuk menguji kekuatan pengaruh tidak langsung $\mathrm{X}$ ke $\mathrm{Y}$ melalui $\mathrm{Z}$. Pengaruh tidak langsung $\mathrm{X}$ ke $\mathrm{Y}$ melalui $\mathrm{Z}$ dihitung dengan cara mengalikan jalur beta $X$ ke $Z$ dengan jalur beta $Z$ ke $Y$ atau ab. Jadi koefisien $\mathrm{ab}$ adalah koefisien pengaruh $\mathrm{X}$ terhadap $\mathrm{Y}$ setelah mengontrol $\mathrm{Z}$. Standard error koefisien a dan b ditulis dengan $\mathrm{Sa}$ dan $\mathrm{Sb}$ dan besarnya standard

* Corresponding author's e-mail: dosen02385@unpam.ac.id http://openjournal.unpam.ac.id/index.php/JABI 
error pengaruh tidak langsung adalah $S_{a b}$ yang dihitung dengan rumus di bawah ini:

$$
S_{a b}=\sqrt{b^{2} S a^{2}+a^{2}} S b^{2}+S a^{2} S b^{2}
$$

Untuk menguji signifikansi pengaruh tidak langsung, maka perlu menghitung nilai $\mathrm{t}$ dari koefisien ab dengan rumus sebagai berikut:

$$
t=\frac{a b}{S a b}
$$

Nilai t hitung dibandingkan dengan nilai t tabel, jika nilai t hitung $>$ nilai t tabel maka dapat disimpulkan terjadi pengaruh mediasi. Asumsi uji sobel memerlukan jumlah sampel yang besar, jika jumlah sampel kecil maka uji sobel menjadi kurang konservatif.

Analisis jalur dengan ketentuan sebagai berikut:

- Jika nilai uji path atau jalur secara langsung > secara tidak langsung maka variabel relevansi nilai tidak intervening atau tidak memediasi.

- Jika nilai uji path atau jalur secara langsung < secara tidak langsung maka variabel relevansi nilai intervening atau memediasi.

\section{ANALISIS DATA DAN PEMBAHASAN}

Tabel 4.1 Hasil Statistik Deskriptif

\begin{tabular}{|l|r|r|r|r|r|}
\hline & \multicolumn{1}{|c|}{$\mathrm{N}$} & Minimum & Maximum & Mean & Std. Deviation \\
\hline IFR & 300 & 0,00 & 1,00 & 0,8400 & 0,36722 \\
DISCLOSURE & 300 & 0,20 & 1,00 & 0,7687 & 0,17720 \\
R2 & 300 & 0,55 & 0,93 & 0,8374 & 0,10900 \\
TOBQ & 300 & $-0,35$ & 0,92 & 0,1359 & 0,17447 \\
Valid N (listwise) & 300 & & & & \\
\hline
\end{tabular}

Sumber: Hasil Pengolahan Data SPSS 22, 2020

Penerapan IFR di dalam perusahaan perbankan yang terdaftar di BEI tahun 20082019 nilai rata-ratanya yaitu sebesar 84\% yang menerapkan IFR, sedangkan sisanya $16 \%$ tidak menerapkan IFR. Pengungkapan informasi dengan nilai rata-rata sebesar $76,8 \%$ menandakan bahwa tingkat pengungkapan informasi industri perbankan yang terdaftar di BEI pada tahun 2008-2019 masuk kedalam kategori fair disclosure atau pengungkapan wajar.

Rata-rata nilai perusahaan sebesar 0,135 yang artinya kurang dari angka 1, hal ini menunjukan bahwa nilai pasar saham lebih kecil daripada nilai bukunya (under value). Hal ini menunjukan bahwa pasar menilai kurang perusahaan tersebut. Nilai tobin's $q$ perusahaan yang rendah (antara 0 hingga 1 ). Semakin besar nilai dari tobin's $q$ semakin besar pula harga sahamnya.

Relevansi nilai perusahaan perbankan yang terdaftar di BEI tahun 2008-2019 mnilai rata-ratanya yaitu sebesar 0,837 atau $83,7 \%$.

* Corresponding author's e-mail: dosen02385@unpam.ac.id

http://openjournal.unpam.ac.id/index.php/JABI 


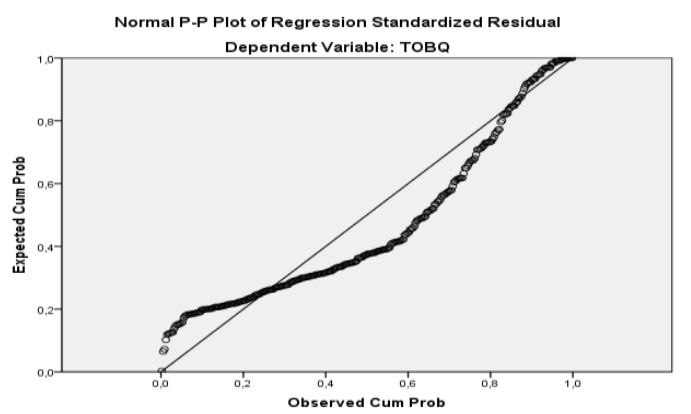

Gambar 4.1 Uji Normalitas Data

Berdasarkan gambar 4.1 di atas, grafik P-Plot menunjukan bahwa titik-titik menyebar di sekitar garis diagonal dan mengikuti arah garis diagonalnya sehingga dapat disimpulkan data terdistribusi secara normal.

Tabel 4.2

\section{Hasil Uji Multikolinearitas (Model 1)}

\begin{tabular}{|ll|r|r|}
\hline \multirow{2}{*}{ Model } & \multicolumn{2}{|c|}{ Collinearity Statistics } \\
\cline { 2 - 3 } & \multicolumn{1}{|c|}{ Tolerance } & \multicolumn{1}{c|}{ VIF } \\
\hline $1 \quad$ (Constant) & & \\
& IFR & 0,946 & 1,057 \\
& DISCLOSURE & 0,946 & 1,057 \\
\hline
\end{tabular}

Berdasarkan tabel 4.2 di atas, dapat dilihat bahwa variabel IFR dan disclosure sebagai variabel independen mempunyai nilai tolerance 0,946 , hal ini berarti tidak adanya kolerasi antar variabel independen. Hasil perhitungan nilai VIF (Variance Inflation Factor) variabel IFR dan variabel disclosure sebesar 1,057. Variabel IFR dan disclosure sebagai variabel independen memiliki nilai VIF kurang dari 10. Dari hasil tersebut, dapat disimpulkan bahwa tidak terdapat multikolinieritas antara IFR dan disclosure sebagai variabel independen.

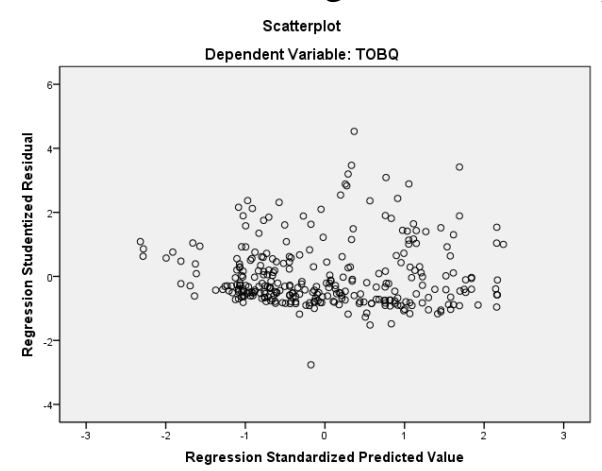

Gambar 4.2

Hasil Uji Heteroskedastisitas

* Corresponding author's e-mail: dosen02385@unpam.ac.id http://openjournal.unpam.ac.id/index.php/JABI 
Hasil uji heteroskedastisitas berdasarkan gambar di atas, model regresi pada penelitian ini tidak terjadi heteroskedastisitas atau bersifat homokedastisitas.

\section{Tabel 4.3}

Hasil Uji Durbin-Watson

\begin{tabular}{|l|r|r|r|r|r|}
\hline & & & \multicolumn{5}{|c|}{ Model Summary $^{\mathbf{b}}$} \\
Model & $\mathrm{R}$ & R Square & $\begin{array}{c}\text { Adjusted R } \\
\text { Square }\end{array}$ & $\begin{array}{c}\text { Std. Error of the } \\
\text { Estimate }\end{array}$ & Durbin-Watson \\
\hline 1 & $0,166^{\mathrm{a}}$ & 0,028 & 0,018 & 0,17292 & 0,727 \\
\hline
\end{tabular}

a. Predictors: (Constant), R2, IFR, DISCLOSURE

b. Dependent Variable: TOBQ

Sumber: Hasil Pengolahan Data SPSS 22, 2020

Berdasarkan tabel 4.3 di atas, nilai DW menunjukan hasil sebesar 0,727 nilai $-2 \leq$ $0,727 \leq 2$, sehingga dapat ditarik kesimpulan bahwa nilai DW tersebut menunjukan tidak terjadi autokorelasi.

\section{Uji Hipotesis}

Analisis Regresi Model 1

$$
\text { Model 1: } \mathbf{Z}=\mathbf{- 0 , 0 6 8} X_{1}+\mathbf{0 , 3 6 8} X_{2}+\varepsilon^{1}
$$

Dari persamaan di atas, maka dapat dijelaskan bahwa:

- Koefisien IFR sebesar -0,068, yang artinya jika IFR naik sebesar 1\%, maka relevansi nilai akan turun sebesar 0,068 atau $6,8 \%$ dengan anggapan variabel-variabel lain tetap.

- Koefisien tingkat pengungkapan informasi (disclosure) sebesar 0,368, artinya jika tingkat pengungkapan informasi (disclosure) naik sebesar 1\%, maka relevansi nilai akan naik sebesar 0,368 atau 36,8\% dengan anggapan variabel-variabel lain tetap

Koefisien Determinasi $\left(\mathbf{R}^{2}\right)$ pada model 1:

Tabel 4.4 Hasil Uji Koefisien Determinasi Relevansi Nilai

\begin{tabular}{|l|c|c|c|c|}
\hline & Model Summary & \\
Model & $\mathrm{R}$ & R Square & $\begin{array}{c}\text { Adjusted R } \\
\text { Square }\end{array}$ & $\begin{array}{c}\text { Std. Error of the } \\
\text { Estimate }\end{array}$ \\
\hline 1 & $0,358^{\mathrm{a}}$ & 0,128 & 0,122 & 0,10212 \\
\hline
\end{tabular}

a. Predictors: (Constant), DISCLOSURE, IFR

b. Dependent Variable: R2

Sumber: Hasil Pengolahan Data SPSS 22, 2020

Berdasarkan tabel 4.4 di atas, koefisien berarti $12,2 \%$ variasi relevansi nilai mampu dijelaskan oleh IFR dan tingkat pengungkapan informasi (disclosure) dan

* Corresponding author's e-mail: dosen02385@unpam.ac.id

http://openjournal.unpam.ac.id/index.php/JABI 
sisanya sebesar $87,8 \%$ dipengaruhi oleh variabel lain yang tidak diteliti dalam penelitian ini.

\section{Uji T-statistik (Uji Parsial) Model 1}

Tabel 4.5 Hasil Uji Statistik t Relevansi Nilai Coefficients $^{\mathrm{a}}$

\begin{tabular}{|ll|r|r|r|r|r|r|}
\hline & & \multicolumn{2}{|c|}{$\begin{array}{c}\text { Unstandardized } \\
\text { Coefficients }\end{array}$} & $\begin{array}{c}\text { Standardized } \\
\text { Coefficients }\end{array}$ & & & \\
\cline { 3 - 6 } Model & \multicolumn{1}{c|}{ B } & Std. Error & Beta & \multicolumn{1}{c|}{ t } & Sig. & Kesimpulan \\
\hline 1 & (Constant) &, 680 &, 027 & & 24,818 &, 000 & \\
& IFR &,- 020 &, 017 &,- 068 & $-1,217$ &, 225 & H1 Ditolak \\
& DISCLOSURE &, 226 &, 034 &, 368 & 6,603 &, 000 & H2 Diterima \\
\hline
\end{tabular}

a. Dependent Variable: R2

Sumber: Hasil Pengolahan Data SPSS 22, 2020

Berdasarkan tabel 4.5 di atas, menunjukkan hasil sebagai berikut:

$\mathrm{H}_{1}$ : Variabel IFR memiliki nilai signifikansi sebesar 0.225 , > 0,05, hal ini menunjukan bahwa IFR tidak berpengaruh terhadap relevansi nilai informasi akuntansi dan berarti $\mathbf{H}_{\mathbf{1}}$ ditolak.

$\mathrm{H}_{2}$ : Variabel disclosure memiliki nilai signifikansi sebesar $0.000<0,05$ hal ini menunjukan bahwa tingkat pengungkapan informasi (disclosure) berpengaruh terhadap relevansi nilai informasi akuntansi dan berarti bahwa $\mathrm{H}_{2}$ diterima.

\section{Uji F-statistik (Uji Simultan) Model 1}

Tabel 4.6 Hasil Uji Statistik F Relevansi Nilai ANOVA $^{\mathrm{a}}$

\begin{tabular}{|ll|r|r|r|r|r|r|}
\hline Model & & \multicolumn{1}{c|}{$\begin{array}{c}\text { Sum of } \\
\text { Squares }\end{array}$} & df & \multicolumn{1}{c|}{$\begin{array}{c}\text { Mean } \\
\text { Square }\end{array}$} & F & Sig. & Kesimpulan \\
\hline 1 & Regression & 0,456 & 2 & 0,228 & 21,849 & $0,000^{a}$ & H3 Diterima \\
& Residual & 3,097 & 297 & 0,010 & & & \\
& Total & 3,553 & 299 & & & & \\
\end{tabular}

a. Predictors: (Constant), DISCLOSURE, IFR

b. Dependent Variable: R2

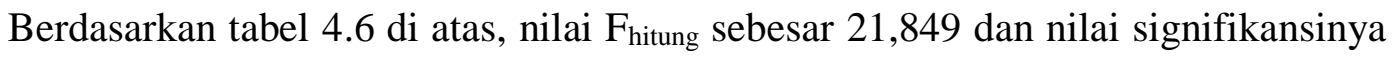
sebesar $0,000<0,05$ atau $5 \%$, maka $\mathrm{H}_{3}$ diterima.

\section{Analisis Regresi Model 2}

$$
Y=0,075 X_{1}+(-0,149) X_{2}+(-0,036) Z+\varepsilon^{1}
$$

Dari persamaan di atas, maka dapat dijelaskan bahwa:

* Corresponding author's e-mail: dosen02385@unpam.ac.id 
- Koefisien IFR sebesar 0,075, yang artinya jika IFR naik sebesar 1\%, maka nilai perusahaan akan naik sebesar 0,075 atau 7,5\% dengan anggapan variabel-variabel lain tetap.

- Koefisien tingkat pengungkapan informasi (disclosure) sebesar -0,149, yang artinya jika tingkat pengungkapan informasi (disclosure) naik sebesar 1\%, maka nilai perusahaan akan turun sebesar 0,149 atau $14,9 \%$ dengan anggapan variabel-variabel lain tetap.

- Koefisien relevansi nilai sebesar -0,036, yang artinya jika relevansi nilai naik sebesar $1 \%$, maka nilai perusahaan akan turun sebesar 0,036 atau 3,6\% dengan anggapan variabel-variabel lain tetap.

\section{Uji Koefisien Determinan $\left(\mathbf{R}^{2}\right)$}

hasil uji koefisien determinasi $\left(\mathrm{R}^{2}\right)$ pada model 2 .

Tabel 4.7 Hasil Uji Koefisien Determinasi Tobin's Q

\begin{tabular}{|l|r|r|r|c|}
\hline & Model Summary & \\
Model & $\mathrm{R}$ & R Square & $\begin{array}{c}\text { Adjusted R } \\
\text { Square }\end{array}$ & $\begin{array}{c}\text { Std. Error of the } \\
\text { Estimate }\end{array}$ \\
\hline 1 & $0,166^{\mathrm{a}}$ & 0,028 & 0,018 & 0,17292 \\
\hline
\end{tabular}

a. Predictors: (Constant), R2, IFR, DISCLOSURE

b. Dependent Variable: TOBQ

Sumber: Hasil Pengolahan Data SPSS 22, 2020

Berdasarkan tabel 4.7 di atas, menunjukkan bahwa $1.8 \%$ variasi nilai perusahaan (Tobin's $Q$ ) dapat dijelaskan oleh IFR, tingkat pengungkapan informasi (disclosure) dan relevansi nilai. Sedangkan sisanya sebesar 98,2\% dipengaruhi oleh variabel lain yang tidak diteliti dalam penelitian ini.

\section{Uji T-statistik (Uji Parsial) pada model 2:}

Tabel 4.8 Hasil Uji Statistik t Tobin's Q

Coefficients $^{\mathrm{a}}$

\begin{tabular}{|c|c|c|c|c|c|c|c|}
\hline \multirow{2}{*}{\multicolumn{2}{|c|}{ Model }} & \multicolumn{2}{|c|}{$\begin{array}{c}\text { Unstandardized } \\
\text { Coefficients }\end{array}$} & \multirow{2}{*}{$\begin{array}{c}\begin{array}{c}\text { Standardized } \\
\text { Coefficients }\end{array} \\
\text { Beta }\end{array}$} & \multirow[b]{2}{*}{$\mathrm{t}$} & \multirow[b]{2}{*}{ Sig. } & \multirow[b]{2}{*}{ Kesimpulan } \\
\hline & & $\mathrm{B}$ & Std. Error & & & & \\
\hline \multirow[t]{4}{*}{1} & (Constant) & 266 &, 081 & & 3,273 &, 001 & \\
\hline & IFR &, 036 & ,028 &, 075 & 1,274 & ,204 & $\mathbf{H}_{4}$ Ditolak \\
\hline & DISCLOSURE &,- 147 &, 062 &,- 149 & $-2,360$ & ,019 & H5 Diterima \\
\hline & $\mathrm{R} 2$ &,- 057 & ,098 &,- 036 &,- 582 &, 561 & H6 $_{6}$ Ditolak \\
\hline
\end{tabular}

a. Dependent Variable: TOBQ

Berdasarkan tabel 4.8, menunjukkan hasil sebagai berikut:

* Corresponding author's e-mail: dosen02385@unpam.ac.id

http://openjournal.unpam.ac.id/index.php/JABI 
H4: Variabel IFR menunjukan nilai signifikansi sebesar 0,204, >0,05 , hal ini menunjukan bahwa IFR tidak berpengaruh terhadap nilai perusahaan (Tobin's $Q$ ) dan berarti bahwa $\mathbf{H}_{\mathbf{4}}$ ditolak.

H5: Variabel tingkat pengungkapan informasi (disclosure) menunjukan nilai signifikansi sebesar 0,019 , < 0,05, hal ini menunjukan bahwa tingkat pengungkapan informasi (disclosure) berpengaruh terhadap nilai perusahaan (Tobin's $Q$ ) dan berarti bahwa $\mathbf{H}_{5}$ diterima.

H6: Variabel relevansi nilai menunjukan nilai signifikansi sebesar 0,561, >0,05 , hal ini menunjukan bahwa relevansi nilai tidak berpengaruh terhadap nilai perusahaan (Tobin's $Q$ ) dan berarti bahwa $\mathbf{H}_{6}$ ditolak.

Uji F-statistik (Uji Simultan)

hasil analisis uji F model 2 dapat dilihat sebagai berikut:

Tabel 4.9 Hasil Uji Statistik F Tobin's Q ANOVA $^{b}$

\begin{tabular}{|c|c|c|c|c|c|c|c|}
\hline \multicolumn{2}{|c|}{ Model } & $\begin{array}{l}\text { Sum of } \\
\text { Squares }\end{array}$ & df & $\begin{array}{c}\text { Mean } \\
\text { Square }\end{array}$ & $\mathrm{F}$ & Sig. & Kesimpulan \\
\hline \multirow[t]{3}{*}{1} & Regression & 0,251 & 3 & \multirow{3}{*}{$\begin{array}{l}0,084 \\
0,030\end{array}$} & \multirow[t]{3}{*}{2,799} & \multirow[t]{3}{*}{$0,040^{\mathrm{a}}$} & \multirow[t]{3}{*}{$\mathbf{H}_{7}$ Diterima } \\
\hline & Residual & 8,851 & 296 & & & & \\
\hline & Total & 9,102 & 299 & & & & \\
\hline
\end{tabular}

a. Predictors: (Constant), R2, IFR, DISCLOSURE

b. Dependent Variable: TOBQ

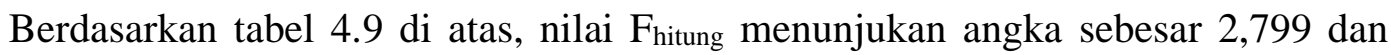
signifikn $0,04<0,05$. Sehingga dapat disimpulkan bahwa variabel IFR, tingkat pengungkapan informasi (disclosure) dan relevansi nilai secara serentak (simultan) berpengaruh positif terhadap variabel nilai perusahaan (Tobin's $Q$ ) dan berarti bahwa $\mathbf{H}_{7}$ diterima.

\section{Analisis Jalur (Path Analysis)}

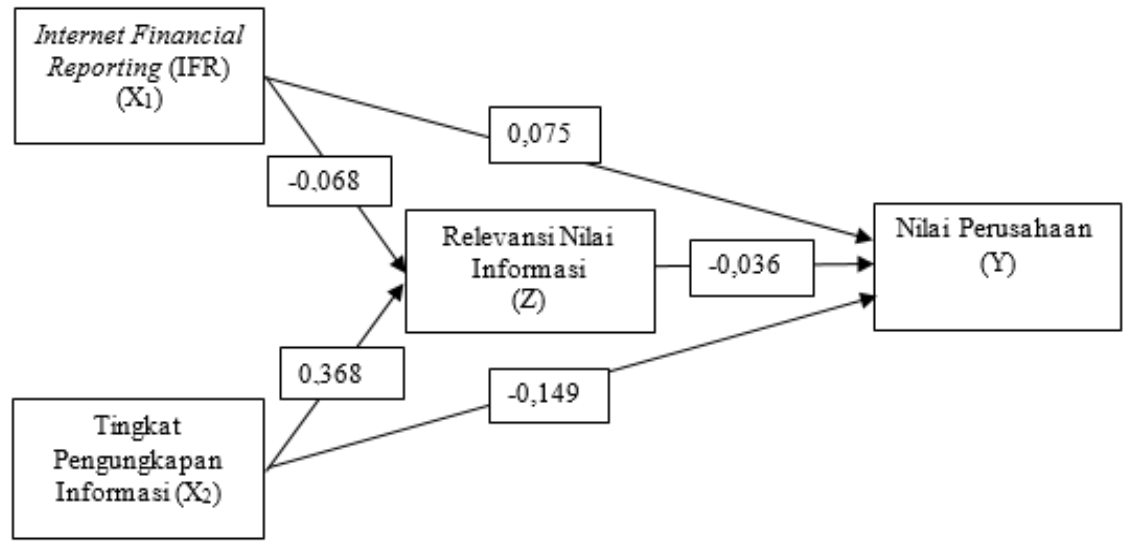

Gambar 4.3 Hasil Uji Path Analysis

* Corresponding author's e-mail: dosen02385@unpam.ac.id http://openjournal.unpam.ac.id/index.php/JABI 
Pengaruh variabel IFR terhadap variabel Nilai Perusahaan melalui atau tidak melalui variabel Relevansi Nilai

Pengaruh langsung $\quad=0,075$

Pengaruh tidak langsung $=-0,068 \times-0,036=0,002$

Total Pengaru $\quad=0,073$

Pengaruh langsung lebih besar daripada pengaruh tidak langsung $(0,075>0,002)$. Sehingga variabel relevansi nilai tidak intervening atau tidak memediasi hubungan antara variabel IFR terhadap variabel nilai perusahaan.

Pengaruh variabel disclosure terhadap variabel Nilai Perusahaan melalui atau tidak melalui variabel Relevansi Nilai

Pengaruh langsung $\quad=-0,149$

Pengaruh tidak langsung $=0,368 \times-0,036=-0,013$

Total Pengaruh $\quad=-0,136$

Pengaruh langsung lebih kecil daripada pengaruh tidak langsung $(-0,149<-$ 0,013). Sehingga variabel relevansi nilai intervening atau memediasi hubungan antara variabel tingkat pengungkapan informasi (disclosure) terhadap variabel nilai perusahaan.

Pengaruh variabel IFR dan disclosure terhadap variabel Nilai Perusahaan melalui atau tidak melalui variabel Relevansi Nilai

Pengaruh langsung $\quad=0,075-0,149=-0,074$

Pengaruh tidak langsung $\quad=(-0,068 \times-0,036)+(0,368 \times-0,036)$

Total Pengaruh

Pengaruh langsung lebih kecil dari pengaruh tidak langsung yaitu $(-0,074<-$ 0,011). Berdasarkan hasil penelitian diperoleh bahwa relevansi nilai merupakan variabel intervening antara IFR dan disclosure secara simultan terhadap nilai perusahaan.

\section{PEMBAHASAN HASIL PENELITIAN}

Dari hasil penelitian di atas menunjukkan bahwa IFR tidak berpengaruh signifikan terhadap relevansi nilai. Perusahaan yang menerapkan IFR dengan baik otomatis memiliki relevansi nilai informasi yang tinggi pula. Semakin baik penerapan IFR semakin tinggi pula relevansi nilai informasi akuntansi perusahaan. Dengan penerapan IFR yang baik memudahkan perusahaan untuk mempublikasikan laporan keuangan secara tepat waktu. Informasi yang diungkapkan melalui IFR secara cepat tersedia bagi semua investor sehingga asimetri informasi akan berkurang dan memperpendek delay aksesibilitas informasi.

Variabel tingkat pengungkapan informasi (disclosure) diuji secara parsial berpengaruh positif terhadap relevansi. Perusahaan dengan tingkat pengungkapan informasi yang fair disclosure, memiliki relevansi nilai informasi yang tinggi. Pengungkapan informasi keuangan maupun non-keuangan, baik secara mandatori

* Corresponding author's e-mail: dosen02385@unpam.ac.id

http://openjournal.unpam.ac.id/index.php/JABI 
maupun secara sukarela di internet dapat meningkatkan transparansi informasi yang lebih besar dan lebih luas didalam pengungkapannya di website perusahaan, investor akan mendapatkan informasi yang relevan dan lebih awal mengenai kondisi perusahaan, sehingga investor dapat bereaksi lebih cepat dalam rangka pengambilan keputusan investasi.

IFR dan tingkat pengungkapan informasi (disclosure) secara simultan berpengaruh terhadap relevansi nilai. Hal ini menunjukkan bahwa implementasi IFR dan tingkat pengungkapan informasi mempengaruhi relevansi nilai. Semakin tinggi penerapan IFR dan tingkat pengungkapan informasi semakin tinggi pula relevansi nilainya.

Bahwa IFR tidak berpengaruh signifikan terhadap nilai perusahaan, karena tingginya penerapan IFR tidak sejalan dengan besarnya nilai perusahaan. Hasil penelitian menunjukan bahwa penerapan IFR nya baik, namun reaksi pasar nya turun, ini terbukti dari nilai pasar saham lebih kecil dari nilai bukunya (under value). Hal tersebut menandakan bahwa pasar menilai kurang perusahaan tersebut, meskipun penerapan IFR nya baik.

Penelitian ini tidak sejalan dengan penelitian yang dilakukan oleh Nur dan Susilowati (2015) yang menyatakan bahwa IFR memberikan pengaruh positif terhadap harga saham, begitu pula terhadap volume perdagangan saham dan berakhir pada nilai saham.

Tingkat pengungkapan informasi berpengaruh terhadap nilai perusahaan . Sementara rata-rata nilai perusahaan yang diproksikan dengan tobin's $q$ sebesar 0,1359 atau $13,59 \%$ yang artinya kurang dari angka 1 , hal ini menunjukan bahwa nilai pasar saham lebih kecil dari nilai bukunya (under value) yang berarti bahwa pasar menilai kurang perusahaan tersebut. Pengungkapan informasi (disclosure) terhadap nilai perusahaan memiliki pengaruh negatif. Hal ini terbukti dari pengungkapan yang wajar tidak sejalan dengan besarnya nilai perusahaan. Hasil penelitian menunjukan bahwa tingkat pengungkapan informasil masuk dalam kategori pengungkapan wajar (fair disclosure), namun reaksi pasar nya turun, hal ini terbukti dari nilai nilai pasar saham yang lebih kecil dari nilai bukunya (under value). Lebih lanjut menurut Chariri (2003), mengungkapkan bahwa dari ketiga konsep pengungkapan hanya konsep adequate disclosure dan fair disclosure yang sering digunakan. Sedangkan konsep full disclosure jarang digunakan karena adanya pertimbangan-pertimbangan khusus dari manajemen antara lain, menimbulkan informasi yang berlebihan, memicu sering munculnya interpretasi yang salah dari pembaca serta tersebarnya informasi penting sehingga bisa melemahkan strategi bersaing perusahaan.

Relevansi nilai tidak berpengaruh terhadap nilai perusahaan. Sementara nilai perusahaan yang dinyatakan dengan tobin's $q$ memiliki rata-rata sebesar 0,1359 atau $13,59 \%$ yang artinya kurang dari angka 1 , hal ini menunjukan bahwa nilai pasar saham lebih kecil dari nilai bukunya (under value) yang berarti bahwa pasar tidak bereaksi terhadap informasi yang masuk di pasar. Hasil penelitian menunjukan bahwa relevansi nilai tinggi, namun nilai pasarnya rendah. Sehingga tidak mempunyai value bagi investor di perusahaan untuk mendapatkan capital gain. Dalam penelitian ini, syarat relevan sudah tercapai, terbukti dengan relevansi nilai nya yang tinggi, namun hasil penelitian menunjukan saham 
memiliki nilai pasar lebih kecil dari nilai bukunya (under value) yang berarti bahwa pasar tidak terpengaruh dengan adanya informasi yang masuk di pasar. Hal ini berarti informasi akuntansi telah kehilangan fungsinya mempengaruhi investor dalam pengambilan keputusan. Saat ini keputusan investasi yang diambil oleh investor banyak dipengaruhi oleh faktor lain selain informasi mengenai keuangan perusahaan, seperti misalnya dipengaruhi oleh para influencer di media sosial mengenai cerita keberhasilan seseorang dalam berinvestasi di suatu saham dan sebagainya.

IFR dan tingkat pengungkapan informasi (disclosure) secara simultan berpengaruh terhadap nilai perusahaan. Penerapan IFR dan disclosure terhadap nilai perusahaan memiliki pengaruh negatif. Hal ini terbukti dari tingginya penerapan IFR dan tingkat pengungkapan informasil tidak sejalan dengan besarnya nilai perusahaan. Hasil penelitian menunjukan bahwa penerapan IFR nya tinggi dan tingkat pengungkapan informasinya pun masuk dalam kategori pengungkapan wajar (fair disclosure), namun reaksi pasar nya rendah, ini terbukti dengan saham yang memiliki nilai pasar lebih kecil dari nilai bukunya (under value). Investor sudah tidak terlalu berfokus pada angka-angka dalam laporan keuangan. Saat ini keputusan investasi para investor banyak dipengaruhi hal lain diluar informasi keuangan perusahaan. Hal tersebut menunjukan bahwa informasi akuntansi telah kehilangan perannya dalam mempengaruhi reaksi pasar. Baiknya penerapan IFR dan tingginya pengungkapan informasi perusahaan, ternyata tidak serta merta memicu kenaikan nilai perusahaan.

\section{KESIMPULAN DAN SARAN}

Dari hasil olah data dan pembahasan dapat ditarik kesimpulan sebagai berikut:

1. IFR berpengaruh positif tidak signifikan terhadap relevansi nilai informasi akuntansi, tingginya penerapan IFR sejalan dengan besarnya revelansi nilai. Penerapan IFR yang baik memudahkan perusahaan untuk mempublikasikan laporan keuangan dengan tepat waktu. Informasi yang diungkapkan melalui IFR secara cepat tersedia bagi semua investor sehingga asimetri informasi akan berkurang dan memperpendek delay aksesibilitas informasi.

2. Tingkat pengungkapan informasi berpengaruh terhadap relevansi nilai informasi akuntansi. Pengungkapan informasi keuangan maupun nonkeuangan, baik secara mandatori maupun secara sukarela di internet dapat meningkatkan transparansi informasi yang lebih besar dan lebih luas didalam pengungkapannya di website perusahaan, investor akan mendapatkan informasi yang relevan dan lebih awal mengenai kondisi perusahaan, sehingga investor dapat bereaksi lebih cepat dalam rangka pengambilan keputusan investasi.

3. IFR dan disclosure secara simultan berpengaruh terhadap relevansi nilai informasi akuntansi. Semakin tinggi penerapan IFR dan tingkat pengungkapan informasi (disclosure) semakin tinggi pula relevansi nilainya.

4. IFR berpengaruh negatif tidak signifikan terhadap nilai perusahaan. Karena tingginya penerapan IFR tidak sejalan dengan besarnya nilai perusahaan. Hasil penelitian menunjukan bahwa penerapan IFR nya baik, namun reaksi pasar nya

* Corresponding author's e-mail: dosen02385@unpam.ac.id

http://openjournal.unpam.ac.id/index.php/JABI 
turun, ini terbukti dengan saham yang memiliki nilai pasar lebih kecil dari nilai bukunya (under value) dan dengan signifikansi sebesar 0,204.

5. Tingkat pengungkapan informasi berpengaruh negatif terhadap nilai perusahaan. Hasil penelitian menunjukan bahwa tingkat pengungkapan informasil masuk dalam kategori pengungkapan wajar (fair disclosure), namun reaksi pasar nya turun.

6. Relevansi nilai tidak berpengaruh terhadap nilai perusahaan. Hasil penelitian menunjukan bahwa relevansi nilai tinggi, namun nilai pasarnya rendah. Sehingga tidak mempunyai value bagi investor di perusahaan untuk mendapatkan capital gain, pasar tidak terpengaruh dengan adanya informasi yang masuk di pasar.

7. IFR dan tingkat pengungkapan informasi berpengaruh negatif terhadap nilai perusahaan. IFR dan tingkat pengungkapan informasi nya bagus namun nilai pasarnya turun. Investor sudah tidak terlalu berfokus pada angka-angka dalam laporan keuangan. Saat ini keputusan investasi para investor banyak dipengaruhi hal lain diluar informasi keuangan perusahaan. Hal tersebut menunjukan bahwa informasi akuntansi telah kehilangan perannya dalam mempengaruhi reaksi pasar. Baiknya penerapan IFR dan tingginya pengungkapan informasi perusahaan, ternyata tidak serta merta memicu kenaikan nilai perusahaan

8. Relevansi nilai merupakan variabel intervening antara IFR dan disclosure secara simultan terhadap nilai perusahaan. Hal ini terbukti dari analisis jalur yang menunjuakan bahwa pengaruh langsung lebih kecil daripada pengaruh tidak langsung.

Adapun masukan yang dapat peneliti berikan dalam penelitian ini adalah:

1. Peneliti menyarankan penelitian berikutnya agar dapat mengembangkan model penelitian dengan menambah variabel lain yang berpengaruh terhadap nilai perusahaan, seperti Capital Adequacy Ratio (CAR), Return On Assets (ROA), Return on equity (ROE), non performing loan (NPL) dan sebagainya. Karena nilai adjusted $\mathrm{R}^{2}$ mengindikasikan variabel nilai perusahaan yang diproksikan oleh Tobin's $Q$ hanya dapat dijelaskan oleh variabel IFR, tingkat pengungkapan informasi (disclosure) dan relevansi nilai sebesar 1,8\% sedangkan selebihnya yaitu $98,2 \%$ dijelaskan oleh faktor-faktor lain diluar model penelitian ini. Selain indeks pengungkapan, kualitas pengungkapan informasi juga perlu untuk diteliti lebih lanjut dengan cara pemberian bobot pada setiap item yang didasarkan pada hasil wawancara atau kuesioner yang ditujukan kepada berbagai pihak yang berkepentingan dengan laporan tahunan perusahaan.

2. Bagi para investor dalam proses pengambilan suatu keputusan investasi perlu kembali menggunakan informasi akuntansi sebagai dasar pengambilan keputusan. Karena saat ini investor dalam proses pengambilan keputusan lebih banyak dipengaruhi oleh sumber-sumber informasi lain diluar informasi akuntansi seperti faktor politik, keamanan, isu, rumor, kebijakan pemerintah, pasar global, dan sebagainya.

* Corresponding author's e-mail: dosen02385@unpam.ac.id

http://openjournal.unpam.ac.id/index.php/JABI 
3. Bagi pemerintah, terkait penerapan IFR, untuk terus memperbaiki dan meningkatkan infrastruktur guna memfasilitasi penerapan IFR dengan lebih baik, agar jaringan internet dapat diakses dengan lebih baik sehingga delay aksesibilitas informasi dapat dikurangi.

\section{DAFTAR PUSTAKA}

Anis Chariri dan Imam Ghazali. (2003). Teori Akuntansi. Semarang: Badan Penerbit Universitas Diponegoro.

Barth, M. E., Beaver, W. H., dan Landsman, W. R. (2008). The Relevance of the Value Relevance Literature for Financial Accounting Standard Setting: Another View. Journal of Accounting and Economics, 31(1-3), 77-104.

Brigham, Eugene F., \& Houston, Joel F. (2013). Dasar-dasar Manajemen Keuangan, Edisi 11 buku 2. Jakarta: Salemba Empat.

Darmawati, D. Khomsiyah, dan R.G. Rahayu. (2004). Hubungan Corporate Governance dan Kinerja Perusahaan. Artikel Simposium Nasional Akuntansi (SNA) VII Denpasar, 382-398.

Emrinaldi, Nur. Dan Enny Susilowati. (2015). Perbandingan Tingkat dan Ruang Lingkup Pengungkapan Pelaporan Kuangan Basis Internet Terhadap Harga Saham. Jurnal Keuangan dan Perbankan, Vol. 19, No. 2. Mei 2015: 252-262.

Elhelaly, M., \& Mohamed, E. K. (2014). A Survey of Internet Financial Reporting in Egypt. International Journal of Accounting and Financial Reporting, 4(1), 70 .

Fama, Eugene F. (1990). Term Structure Forecast of Interest Rates, Inflation, and Real Return. Journal of Monetary Economics, 25, 59-76.

Francis, Jeniffer and Katherine Schipper. (1999). Have Financial statement Lost Their Relevance. Journal of Accounting. 37.p.319-352.

Jones, Charles P. 2009. Investments analysis and management, (10th Ed.). New Jersey: John Wiley \& Sons, Inc.

Khan, M. N. A. A., \& Ismail, N. A. (2011). The level of internet financial reporting of Malaysian companies. Asian Journal of Accounting and Governance, 2, 27-39.

Khan, D. M., \& Ismail, P. D. (2011). The Use of Disclosure Indices in Internet Financial Reporting Research. Journal of Global Business and Economics, $3(1)$.

Lai, S.C., C. Lin, H.C. Li, dan F.H. Wu. (2009). An Empirical Study of The Impact of Internet Financial Reporting on Stock Prices. The International Journal of Digital Accounting Research. 10(1): 1-26.

* Corresponding author's e-mail: dosen02385@unpam.ac.id

http://openjournal.unpam.ac.id/index.php/JABI 
Lev, Baruch, and Paul Zarowin. (1999). The Boundaries of Financial Reporting and How to Extend Them. Journal of Accounting Research, Vol. 37, 353385 .

Murtanto dan Elvina. (2005). Pengaruh Karakteristik Perusahaan terhadap Pengungkapan Sukarela dalam Laporan Tahunan Perusahaan yang Terdaftar dalam BEJ. Ekonomi dan Bisnis UNISSULA, Vol. 6, No. 1, 4757.

Pinasti, Margani. (2004). Faktor-faktor yang Menjelaskan Variasi Relevansi-Nilai Informasi Akuntansi: Pengujian Hipotesis Informasi Alternatif, Simposium Nasional Akuntansi VII.

Rosmaini, S., Ariff, M., Kamil, M., Hancock, D.R. (2009). Business Reporting on the Internet: Development of a Disclosure Quality Index. International Journal of Business and Economics, Vol. 8, No.1: 55-79.

Salvatore, Dominick. (2005). Ekonomi Manajerial dalam Perekonomian Global. Jakarta: Salemba Empat.

Santoso, Singgih. (2010). Panduan Lengkap Menguasai Statistik dengan SPSS 17. Jakarta: Penerbit PT. Elex Media Komputindo.

Soemarso, S.R. (2003). Akuntansi Suatu Pengantar (Buku 2). Jakarta: Salemba Empat.

Sugiyono. (2012). Metode Penelitian Kuantitatif Kualitatif dan R\&B. Bandung: Alfabeta.

Suwardjono. (2005). Teori Akuntansi. Edisi 3. Yogyakarta: BPFE. 